\title{
The Relative Clause and its Tones in Tswana ${ }^{1}$
}

\author{
Sabine Zerbian \\ Department of Linguistics, University of Potsdam
}

The morpho-syntax of relative clauses in Sotho-Tswana is relatively welldescribed in the literature. Prosodic characteristics, such as tone, have received far less attention in the existing descriptions. After reviewing the basic morphosyntactic and semantic features of relative clauses in Tswana, the current paper sets out to present and discuss prosodic aspects. These comprise tone specifications of relative clause markers such as the demonstrative pronoun that acts as the relative pronoun, relative agreement concords and the relative suffix. Further prosodic aspects dealt with in the current article are tone alternations at the juncture of relative pronoun and head noun, and finally the tone patterns of the finite verbs in the relative clause. The article aims at providing the descriptive basis from which to arrive at generalizations concerning the prosodic phrasing of relative clauses in Tswana.

\section{Introduction}

The morphological, morpho-syntactic and syntactic characteristics of the relative clause in Tswana (and in the Sotho-Tswana group S30 in general) are well-described in reference grammars of the languages, such as Cole (1955: 171ff) for Tswana or Ziervogel et al. (1969: 105ff) for Northern Sotho. This is due to the fact that relative clauses in Sotho-Tswana are clearly marked morphologically and morpho-syntactically by a relative suffix and a relative pronoun, as will be illustrated in section 2. Phonological and tonal characteristics of the relative clause and its prosodic embedding into the phrase

1 This work was presented at the workshop on relative clauses in Bantu, organized by the Franco-German Research Project Phonology-Syntax Interface in Bantu Languages and held in January 2010 in Paris. I thank the organizers and project leaders, Laura J. Downing and Annie Rialland, for the invitation. The work could have not been prepared without Rev. Mascher's thorough knowledge of the Tswana language and the financial support of the Department of Science \& Technology, South Africa, through a grant to the project "Phonetics for Advanced Speech Technology". 
are considerably less well-described for two reasons, namely the lack of a comprehensive tonal grammar of any of the Sotho languages and the disjunctive orthography. First, no complete tonal grammar of the Sotho-Tswana languages exists as yet. Reference grammars in general do not mark tone, thus although they provide a thorough description of the morpho-syntax, they do not cover phonological aspects such as phrasing or tone. Specialized studies on different aspects of the tonal system and phrasing in the Sotho-Tswana languages are available (Chebanne et al. 1997, Mmusi 1992, Khoali 1991, Monareng 1992, Lombard 1976). But given their place at the intersection of syntax, verb morphology and phrasal phonology hardly any phonological and tonal aspects of the relative clause have been covered in these treatments. Second, the disjunctive writing system, which is used in Tswana and which treats verbal prefixes as independent orthographic words, obscures the prosodic constituency in the verb complex.

The aim of this article is therefore to provide an outline of the morphological, morpho-syntactic and phonological properties of the relative clause in Tswana. It concentrates on phonological and tonal aspects in order to fill a gap in the descriptive literature of this language. Although reference to other languages of the Sotho-Tswana group will be made at times, especially to Northern Sotho, it cannot be claimed that this article makes an independent investigation into the other Sotho-Tswana varieties obsolete.

The article is structured as follows: Section 2 provides a brief review of the morpho-syntactic and morphological characteristics of the relative clause in Tswana. Section 3 provides examples of relative clauses which exemplify the general points made in section 2 in several different syntactic constellations. Section 4 briefly addresses the linguistic uses of the relative clause in Tswana, which correspond to uses in other Bantu languages. Section 5 and 6 address phonological characteristics of the relative clause. Section 5 discusses the phrasing of the relative clause with respect to its head noun as well as with respect to following constituents. Section 6 discusses the tones of the verbal tenses in the relative clause. Section 7 summarizes the observations made and points out areas for further research.

\section{Morpho-syntactic characteristics of the relative clause in Tswana}

The phrase in (1) shows a head noun followed by a relative clause by means of which the morphological and morpho-syntactic characteristics of the relative clause in Tswana will be exemplified. In all examples, high tones are marked by acute accent and underlying tones are underlined. The circumflex does not 


\section{indicate tone but refers to vowel quality and differentiates the mid vowels $e$} and $0^{2}$

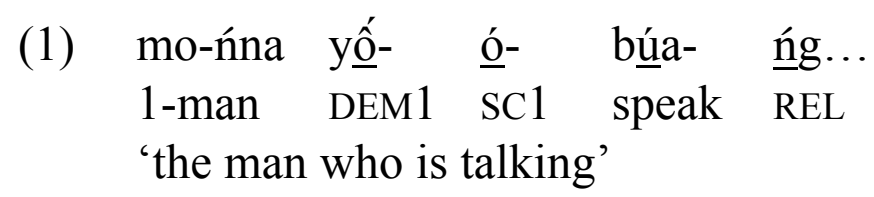

Relative clauses in Tswana show an obligatory relative pronoun (Zeller 2004) in the example in (1) yố- - which is identical in form and tone to the demonstrative pronoun; however, it has lost its demonstrative significance (Cole 1955). In Northern and Southern Sotho, the relative pronoun occasionally merges with the following subject marker in direct relative clauses (Mischke 1998; see Doke 1954, Cole 1955 for terminology and example (2) for an exemplification of a direct relative). The use of the relative pronoun is similar to relative clause formation in the eastern neighbor Tsonga but different from the pattern found in the southern neighbor Zulu (cf. Zeller 2004).

The obligatory subject concord (SC in the glosses, for a list of abbreviations see footnote 3 ) in relative clauses is formally and tonally identical to the one in subordinate tenses but with $\underline{o}$ (instead of $\underline{a}$ ) in noun class 1 , at least as an alternative (Chebanne et al. 1997 list it as free variation, Cole 1955: 173 lists it as dialectal variation).

The finite verb of the relative clause is in the participial tense (Cole 1955, Chebanne et al. 1997), as will be discussed in section 6 in more detail. The most important marker of the participial tense in comparison to the principal tense is tone.

Tswana has the relative clause affix - $\underline{n g}$ (in Northern Sotho also -go) which is obligatorily suffixed to the finite verb of the relative clause and thus consistently marks the relative clause formally. This is again similar to Tsonga $k o$, but in contrast to Zulu where a relative suffix $-y o$ is only found in some tenses and only if the verb is final in the relative clause (Zeller 2004).

2 The glosses used in this paper are the following:

$\begin{array}{llll}\text { number } & \text { referring to noun class or person } & \text { SG } & \text { singular } \\ \text { DEM } & \text { demonstrative } & \text { PL } & \text { plural } \\ \text { SC } & \text { subject concord } & \text { PROP } & \text { proper name } \\ \text { REL } & \text { relative suffix } & \text { PERF } & \text { perfect } \\ \text { POSS } & \text { possessive concord } & \text { PASS } & \text { passive } \\ \text { OC } & \text { object concord } & \text { NEG } & \text { negation } \\ \text { ABS } & \text { absolute pronoun } & \text { FUT } & \text { future } \\ \text { REFL } & \text { Reflexive pronoun } & \text { PR } & \text { pronoun }\end{array}$




\section{Examples of relative clauses in Tswana}

This section provides examples that illustrate the morpho-syntactic and morphological characteristics presented in section 2. As a rule of thumb the head noun of the relative clause, i.e. the antecedent for the relative pronoun, is always represented twice in the relative clause in Tswana and is marked in bold in examples (2)-(11) for ease of reference. For the same reason, the relative clause is delineated by square brackets. The terminology for (2) and (3) has been introduced by Doke (1954) and Cole (1955).

(2) Subject relative - 'direct relative'

$\begin{array}{lllll}\text { mo-ńna } \quad\left[\begin{array}{l}\text { yố- } \\ \text { 1-man }\end{array}\right. & \underline{\mathbf{o}}^{-} & \text {béa- } & \text { ńg] } \\ \text { 'the man who is talking } & \text { SC1 } & \text { speak } & \text { REL }\end{array}$

In object relative clauses, as in (3), an object concord (OC) on the relative verb is obligatory, although object marking might otherwise be considered pronominal in Tswana, just as it is in Chichewa (Bresnan \& Mchombo 1987). Also note that in contrast to e.g. Luganda (Hyman \& Katamba, this volume) or Shona (Demuth \& Harford 1999), subject inversion is not possible in relative clauses in Tswana.

(3) Object relative - 'indirect relative' (Cole 1955, §10.13)

$\begin{array}{llllll}\text { di-lô } \quad[\text { ts } \underline{\text { ế- }} & \text { ké- } & \text { dị- } & \text { ráta- } & \underline{\text { ńg}}] \\ \text { 10-thing } & \text { DEM10 } & \text { SC1SG } & \text { OC10 } & \text { like } & \text { REL } \\ \text { 'the things that I like' } & & & \end{array}$

Note that in all relative clauses the resumption of the head noun in the relative clause is obligatory (marked in bold).

(4) Subjectival possessive (Cole 1955, §10.14)

mo-sạdi [yố- ngwaná wáa gạ́gwê̂́ ó- lwála- ńng] 1-woman DEM1 1.child POSS1 POSSPR1 SC1 be.sick REL 'the woman whose child is sick'

(5) Objectival Possessive (Cole 1955, §10.15)

$\begin{array}{lllll}\text { di-thaba } & \text { [ts } \underline{\hat{e}}^{-} & \text {ma-fíka } & \text { á- } & \text { tsôná } \\ \text { 10-mountain } & \text { DEM10 } & \text { 6-stone } & \text { POSS6 } & \text { ABS10 } \\ \text { ré- } & \text { bốna- } & \text { ńg } & \text { kájênó] } & \\ \text { SC1PL } & \text { see } & \text { REL } & \text { today } & \\ \text { 'the mountain } & \text { whose rocks we see today' } & \end{array}$


(6) Associative adverbial (Cole 1955, §10.17)

ba-ńna [bá- ré- dúmếlána- ńg lé- bônế $]$

2-man DEM2 SC1PL agree REL with ABS2

'the men with who we agree'

(7) Instrumental adverbial (Cole 1955, §10.18)

thipá [ [ế- ré- séga- ńg nama ká- yônế $]$

9.knife DEM9 SC1PL cut REL 9.meat with ABS9

'the knife with which we cut the meat'

(8) Locative adverbial (Cole 1955, §10.21)

Tshwane [kwáa- kée ńna- ńg têńg ${ }^{3}$ ]

PROP DEM18 SC1SG live REL there

'Tshwane where I live' (Tshwane= Pretoria)

In some dialects of Haya (Riedel, this volume) the relative marker and the subject marker match even in the first and second person. In Tswana, this kind of agreement pattern is not possible as no demonstrative pronoun exists for first or second person. If a first or second person pronoun is relativized, the relative pronoun of classes 1 (SG) or 2 (PL) is used, as exemplified in (9).

(9) $1^{\text {st }}$ and $2^{\text {nd }}$ person (Mascher, Conv 46E III)
[Bá- lón- ráta-
ńg di-kúkú]
DEM2 SC2PL love
lo- tlaa- sényếgêl-wa ké-mênố.
SC2PL FUT damage-PASS by-teeth
'You (pl.) who like biscuits will get the teeth damaged.'
(cf. Cole 1955: 171)

In Tswana there also exists a shortened form of the relative clause in which the auxiliary verb can optionally be dropped, as exemplified in (10). However, this is only possible in the present positive tense.

3 Note that this -ng does not mark a relative form nor does it mark a locative, which has a low-toned -ng suffix. 
(10) Short form (Mascher, Conv 46C III)

Re-ítshwárếla [báa- báa mélató lé-roná].

SC1PL-forgive DEM2 SC2 5.problem with-ABS1PL

$\begin{array}{llll}< & \text { bá- } & \text { bá- } & \text { le-ńg } \\ \text { DEM2 } & \text { SC2 } & \text { be.with-REL }\end{array}$

'We forgive those who owe us'

With compound verb tenses, the relative suffix $-n g$ only suffixes onto the first verb stem, as exemplified in (11).

(11) With compound verb tense

Ma-gôdu [á́- áa- nê- ñng ạ́- tšhwếr-wé málôba] áa-golóts-wế. 6-thief DEM6 SC6 be REL SC6 arrest-PASS recently sC6-release-PASS 'The thieves who had been arrested the other day have been released.'

\section{Use of relative clauses}

Relative clauses are used for noun modification as shown in the examples in section 3. Given that in general Bantu languages only have a very small class of genuine adjectives (Cole 1955: 138), relative clauses in Tswana are frequently used for nominal modification that would be expressed through adjectives in languages such as English. An example is given in (12).

(12) Short relative clauses as "adjectives" (Cole 1955: 175)

ba-ná báa bá- maaka

2-child DEM2 SC2 lie

'untruthful children'

Relative clauses are also used for clefting. Also here, an increased frequency of occurrence might be observed due to the fact that one way of focusing or questioning logical subjects is by use of a cleft sentence, as illustrated in (13).

(13) Relative clauses in clefts

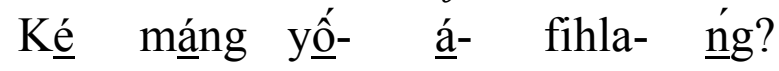

COP who DEM1 SC1 arrive REL

Lit. 'It is who that arrives?' = 'Who arrives?'

Diachronically, Creissels derives the last mentioned use of clefts, namely for focusing, from the primary use as modifiers by stating that "les formes relatives du verbe tswana s'emploient typiquement comme noyau prédicatif de relatives restrictives, et il semble raisonnable de penser que leurs autres emplois 
(notamment dans les phrases clivées exprimant une focalisation) sont historiquement dérivés de leur emploi dans la relativisation" (2002:106).

Although there is generally a semantic distinction between restrictive and non-restrictive relative clauses, this distinction does not seem to have prosodic consequences in Tswana. This is in contrast to Bemba where tonal marking can only occur on restrictive relative clauses (Cheng \& Kula 2005 for Bemba). Likewise, the grammaticalization of clefts as focus constructions for subjects could have resulted in prosodic consequences. This is the case in Zulu where there are differences in prosody concerning cleft and restrictive/non-restrictive relative clause in that clefts and non-restrictive relative clauses but not restrictive relative clauses show a prosodic phrase break between head noun and relative clause (Cheng \& Downing 2007, to appear). Again, this does not seem to be the case in Tswana.

In Tswana it seems as if the prosody of modified nouns, relative clauses, and clefts is purely syntactically determined, without prosodic modifications due to semantics of the kind mentioned above for Bemba or Zulu. The prosody will be spelt out in the following section in more detail. A reason why the prosodic embedding of a relative clause resembles modification so closely in Tswana might lie in the diachronic development of the relative clause from a demonstrative pronoun which is still clearly evident synchronically (cf. Zeller 2004) even though the demonstrative has lost its meaning and might even be merged phonologically with the following verb word in some Sotho-Tswana varieties (cf. Mischke 1998).

\section{Tonal embedding of the relative clause}

Tonal modifications can be observed when a relative clause is embedded in a phrase, again exemplified with the sentence in (1), here repeated as (14).

$$
\begin{aligned}
& \text { (14) mo-ńna [yố- } \text { ó- búa- ㅁg...] } \\
& \text { 1-man DEM1 SC1 speak REL }
\end{aligned}
$$

The final syllable of the head noun, if low-toned, is exempt as a target of high tone spread (cf. Creissels 1998: 187). High tone spread (HTS) is a tonal rule which spreads an (underlying) high tone onto right-adjacent syllables (the number of syllables which act as target for HTS differs, cf. Creissels 1998, 1999, 2000). In Tswana this is possible within and across words, as exemplified in $(15 \mathrm{a}+\mathrm{b})$ respectively (marked in bold). 
(15) examples from Cole \& Mokaila (1962: 7)

a. Ó-ápaya di-jố.

SC1-cook 10-food

'She is cooking food.'

b. Ó-dísá dí-kgômó.

sc1-herd 10-cow

'He herds the cattle.'

If the targeted syllable is word-final and a word which starts with a high tone follows the targeted syllable, HTS is only possible at the juncture of subject and verb, (16a), and verb and object, (16b), as marked in bold.

(16) examples from Cole \& Mokaila (1962: 7)

a. Mo-sádí ó-ápaya di-jố.

1-woman SC1-cook 10-food

'The woman is cooking food.'

b. Ke-tla-rếká pódi.

1SG-FUT-buy 9.goat

'I will buy a goat.'

High tone spread onto the final syllable of word when it is followed by a hightone initial word is not possible in modification structures, such as objectlocative sequences, (17a), instrumental modification, (17b), modal modification, $(17 \mathrm{c})$, noun-modifier sequences, $(17 \mathrm{~d})$, or head noun-relative clause sequences, (17e).

(17) examples from Cole \& Mokaila (1962: 30, 26, 10, 24, 47)

a. Ngwêdí ó-tsến-ye mố-má-ru-ng.

9.moon 1-enter-PERF LOC-6-cloud-LOC

'The moon has gone into the clouds.'

b. A o-tsháméka ká-mó-gomá?

Q 2sG-play with-3-plough

'Are you playing with the plough?'

c. Ba-sétsána bá-búa tháta.

2-girl SC2-talk much

'Girls talk a lot.' 

d. Mo-rúti wáá-ba-ná
ó-gôrốg-ílê
léng?
1-teacher POSS1-2-child SC1-arrive-PERF when
'When has the school teacher arrived?'
e. Ke-rákán-ye lé-mo-ñna yố-ó-ségô.
1SG-meet-PERF with-1-man DEM1-SC1-luck
'I met a lucky man.'

The asymmetry between (16) and (17) calls for an analysis in terms of prosodic phrasing. However, a possible analysis is not straightforward. Given the occurrence of HTS in sequences of verb-object, a first hypothesis would be that the blocking of HTS in (17) occurs at phrase boundaries and is thus indicative of them. This approach would assume a phrase boundary after the head noun of the relative clause in (14) and more generally after every modified head noun. Though not implausible, this is contrary to what has been found in other Bantu languages, such as Chichewa (Kanerva 1990) and Xhosa (Jokweni 1995), and therefore needs careful investigation. For now, we take note of this observation only and leave the detailed analysis a topic for future research.

As for the demonstrative pronoun which acts as a relative pronoun, it is procliticized to what follows (either verb or noun, Cole in press: §172). It is always high-toned. Subject concords in the relative clauses are also always hightoned (see section 5). If a high-toned verb stem follows the subject concord, as in (14), a sequence of three adjacent underlying high tones occur. This is rare in the verbal grammar of Tswana. If, for example, three consecutive high tones occur in other structures, as in (18), the middle high tone is regularly lowered.

(18) examples from Cole \& Mokaila $(1962: 38,40)$

a. Ga-bá-bọ-rát-e.

NEG-SC2-OC14-like-NEG

'They don't like it, e.g. beer.'

b. Ke-batla go-sé-ị-thếkếlá.

1SG-want 15-OC7-REFL-buy.for

'I want to buy it for myself.'

Again, the observation that three high tones can occur consecutively in verbs in the relative clause is telling for the prosodic constituency in this construction, although details of an analysis must remain a topic for future research.

Another observation is that the suffixation of the relative marker $-\underline{n g}$ prevents the preceding syllable from acting as a target for high tone spread, i.e. * 
mo-ńna yố -ó-búá-ńg. It thus regularly enforces a low tone on the verbstemfinal, new penultimate syllable (Chebanne et al. 1997: 199; with the common restrictions, i.e. LH- $n g \rightarrow * L L-n g)$. This word-internal phenomenon is parallel to the phrase-level phenomenon illustrated in (17).

Finally, one can observe high tone spread from the high-toned relative suffix $-\underline{n g}$ onto a following low-toned noun prefix, as illustrated in (19).

\begin{tabular}{|c|c|c|c|c|c|}
\hline Di-taú & [tsế- & dí- & j-élê- & ńg & dí-kgômó] \\
\hline 10-lion & DEM 10 & $\mathrm{SC} 10$ & eat-PERF & REL & $10-$ cow \\
\hline
\end{tabular}

\section{The tone pattern of the "relative tenses"}

\subsection{Relative and participial tenses}

The current section has a closer look at the tone patterns on the verb stem itself which are due to its appearance in a relative clause. First, it needs to be noted that some languages, e.g. Bemba (Cheng \& Kula 2005), indicate restrictive subject relative clauses solely by tone-marking. Although the tones of the subject marker also change in relative clauses in Tswana, one cannot say that relative clauses can be indicated solely by tone in Tswana because first, the tones of the subject marker are mostly ambiguous between participial tense and relative tense as will be shown below, second, there is also the relative pronoun (although it can be dropped in specific instances, cf. Cole 1955), and third the relative suffix $-\underline{n} g$ is obligatory. Only perception tests can show which of the cues - tone or suffix - is more important in Tswana.

Cole (1955: 178) states that "direct relatives and relative clauses are formed from participial verb tenses by substituting the relative concord for the subjectival concord, and suffixing $-\underline{n g}$ to the verb." He shows that relatives are based on the participial forms of the verb tenses, i.e. on those tense forms which occur in subordinate clauses, and not on the principal form. He shows this by reference to the negative form in which the relative, just as the participial form, has the negative morpheme $-s a-$, whereas the principal form has $g a-$, as marked in bold in (20).

Ngwana ga-a-lel-e 'The child is not crying' (principal tense)

Fa ngwana a-sa-lel-e... 'If the child does not cry...'(participial tense) ngwana yô-o-sa-lel-e-ng 'the child who does not cry'(relative tense) 
The verb forms in the relative tense and the participial tense do not only correspond to each other in negative formation by having the same negation particle $-s a$ - in the same position, namely following the subject concord, but they also largely correspond in their tone patterns. There are two differences though: the subject concord of CL1 is $\underline{\underline{o}}$ - instead of $\underline{a}$ - in all tenses (at least as free variation or as dialectal variation) and the tone pattern in the Present Positive. Section 6.2 first shows the correspondence of tone patterns in most of the tenses, and then discusses the case of the Present Positive in section 6.3.

\subsection{Correspondence between relative and participial tenses}

The present tense and the perfect tense are the only two synthetic tenses in Tswana. All other tenses, such as the future tense, the past perfect etc., are compound tenses and are composed of at least one of the tenses mentioned in the first sentence (Cole 1955). Only the synthetic tenses will be discussed in this paper.

\subsubsection{Present negative}

In the present negative, both the participial and the relative tense are characterized by high-toned subject concords in all noun classes, the negative particle $-s a$ - and a verb stem ending in $-e$. Tonally, they show grammatical tone on the second verb stem syllable, and iterative tone spread to the end of the domain (cf. Khoali 1991). As mentioned in section 5, the stem-final syllable is always low before the high-tone relative suffix $-\underline{n} g$. Apart from the lowered syllable before $-\underline{n} g$, the participial tense and the relative tense are identical in tone, as illustrated in (21) in the bold marked verb forms. The conjunction fá introduces a subordinate clause in Tswana which takes the participial verb form in the respective tense.

(21) all examples from Cole \& Mokaila (1962: 49f)
a. Particip.

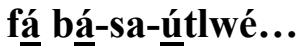
Relative Ga-ké-ráté baná
[bá-bá-sa-úttlwe-ńg
batsádi bá-bônế].
I do not like children
DEM2-SC2-NEG-listen-REL
their parents
'I don't like children who do not listen to their parents.'

\footnotetext{
4 For reasons of space and ease of reference, morpheme boundaries in words other than the relative verb word are only indicated for those morphemes that are written separately in Tswana orthography in examples (21)-(23).
} 
b. Particip.

fá á -sa-ịttsé...

Relative

A gó-na lé-mótho

[yố -óo-sa-ítse-ńg

ngwêdí lé-létsatsí]?

There is noone

DEM1-SC1-NEG-know-REL

moon and sun

'Is there a person who does not know moon and sun?'

c. Particip.

Relative

fá sé-sa-ị-tirếlé...

Mothibi ké-sétšhwakga

[sế-sế-sa-í-tirếle-ńg

sépê].

Mothibi is a lazy person DEM7-SC7-NEG-REFL-do_for-REL thing

'Mothibi is a lazy person who does not do anything for himself.'

\subsubsection{Perfect positive}

In the perfect positive, both the participial and the relative tense are characterized by high-toned subject concords in all noun classes, grammatical tone on the second stem syllable, and iterative tone spread (cf. Khoali 1991). Again, the stem-final syllable is always low before the high-toned relative suffix $-\underline{n} g$. Otherwise, participial tense and relative tense are identical in tone, as illustrated in (22) in the verb forms marked in bold.

(22) all examples from Cole \& Mokaila (1962: 66f)
a. Particip.
fá á ágág-íl-wế...
$\begin{array}{ll}\text { Relative } & \text { Ke-rátá matlo } \\ & \text { I like houses }\end{array}$
[ä́-á-ág--íl-wê-ńg
ká-seténá].
DEM6-SC6-build-PERF-PASS-REL
with-brick
'I like houses which are built of brick.'

b. Particip.
Relative

Batho bá-rátá nama
people like meat

fá é-bês-íts-wế ...

[ế-é-bês-íts-wê-ńg

ká-mólelô]. DEM9-SC9-roast-PERF-PASS-REL with-fire

'People like meat which has been roasted on the fire.'

c. Particip.

fá bóo-apế-íl-wế...

Relative

$\begin{array}{ll} & \text { fá } \mathbf{b} \text { bó-apế-íl-wế... } \\ \text { Ke-rátá bogốbe } & \text { Ijố-bó-apế-íl-wê-ńg } \\ \text { I like porridge } & \text { DEM14-sc14-cook-PERF-PASS-REL } \\ \text { 'I like porridge which has been cooked with milk.' }\end{array}$

ká-maši].

with-milk

\subsubsection{Perfect negative}

In the perfect negative, both the participial and the relative tense are characterized by high-toned subject concords in all noun classes, negative particle $-s a$ - and verb stem ending in $-a$ (ga-SC-aa-R-a in the Principal tense). Tonally, they show grammatical tone on the second stem syllable, and iterative 
tone spread (cf. Khoali 1991). Again, the stem-final syllable is always low before the high-tone relative suffix $-\underline{n} g$. Otherwise, the participial tenses and the relative tenses are identical in terms of tone, as illustrated in (23) in the bold marked verb forms.

(23) Examples from Cole \& Mokaila (1962: 66f)
a. Particip.
Relative
ga-ó-batlé dikgóng
fá dí-sa-ốmá...
It does not want
[tsế-dí-sa-ốma-ńg
DEM10-SC10-NEG-be_dry.PERF-REL
tháta].
very
'It (i.e. a fire) does not want wood which is not very dry.'
b. Particip.
Relative

Ga-á-batlé Makgóa

fạ á-sa-ịthútá ...

It doesn't want Whites

[áa-á-sa-íthúta-ńg

Setswána].

DEM6-SC6-NEG-learn.PERF-REL Tswana

'It (e.g. the government) does not want Europeans who have not learnt Tswana.'

c. Particip.

Relative

BáBatswạná gabạ́rạté bańna

fá bá-sá-rupá ...

[báa -bá-sá-rupá-ńg].

DEM2-SC2-NEG-initiate.PERF-REL

'The Tswana (women) do not like men who have not gone through initiation.'

For the tenses above, one can generalize that the relative forms do not only correspond to the participial forms in morpho-syntax but also in tone.

\subsection{The present positive in the relative}

The following table follows Chebanne et al. (1997) and shows the tonal differences in the comparison of participial tense (termed "gérondif") and relative tense in high-toned verb stems in the present positive.

Table 1: Tone patterns of the present positive

\begin{tabular}{|c|c|c|}
\hline Chebanne et al. 1997 & participial & relative tense \\
\hline monosyllabic $\mathrm{H}$ & lóo-jáá & [bá bá-jâa-ńg] \\
\hline disyllabic H & ó-biná & [bá bá-kwála-ńg] \\
\hline trisyllabic $\mathrm{H}$ & ó-bêrếká & [bá bá-bếrếka-ńg] \\
\hline quatrosyllabic $\mathrm{H}$ & ló-bêrrếkếla & [bá báá-tshámékísa-ńg] \\
\hline monosyllabic L & ó-tlá & [bá ré-ya-ńg] \\
\hline
\end{tabular}




\begin{tabular}{|l|l|l|}
\hline disyllabic L & $\underline{\text { á}-l i ́ m a ́ ~}$ & [bá bóá-bála-ńg $]$ \\
\hline trisyllabic L & ló́-tsámáya & [bá bá-ếtếla-ńg] \\
\hline quatrosyllabic L & báá-tlhálóganya & [báa bá-dúmếdisa-ńg] \\
\hline
\end{tabular}

Mascher (in prep.: Gram 100) adds the observation that the high tone spread in the present positive relative tense takes place iteratively, just as in other tenses in which a grammatical high tone is inserted. This is exemplified in (24) for lowtoned verb stems (in contrast to [bá bá-dúmếdisa-ńg] in table 1).

(24) Iterative High Tone Spread (marked in bold)

a. [bá ké-bátlísísa-ńg]

b. [bá ké-lékálékánya-ńg]

Thus, two differences emerge in the comparison of participial tense and relative tense in the present positive: First, with high-toned verbs, the stem-initial syllable is never lowered in the relative tense, and second, with low-toned verbs HTS takes place iteratively (just as in the present negative, perfect positive and negative), at least in the Rolong variety (Cole \& Mokaila 1962, Mascher in prep.).

The first observation is explicitly confirmed by Chebanne et al. (1997: 199) and Creissels (2002: 104) by stating that "Le gérondif [= participial, SZ] des verbes à tons lexical haut est caractérisé au présent positif par une alternance tonale qui ne se retrouve pas dans le forme relative correspondante (par exemple, le gérondif présent de -símólóla "commencer" avec un indice de sujet de classe 1 est á-simólóla, mais la forme relative correspondante est á-símólólańg."

Chebanne et al. (1997: 185ff) account for the lowered stem-initial syllable of high-toned verb stems in the Present Participial Tense by positing an underlying empty syllable at the junction between the subject concord and the stem. If the subject concord is immediately followed by a lexically toneless stem, however, the tonal melody is not the one which would be expected if an empty syllable were still present after the subject concord as the spreading of the high tone of the subject concord reaches the second syllable of the stem. They do not see any other solution than to posit two variants of the structure of this tense.

Mascher (in prep., Gram 40C) analyses the participial tense as being formed with a "lingering" low tone which pulls down the first syllable of a high stem but vanishes into a low stem. The subject marker to its left is nevertheless able to spread its high tone. 
In the present positive of the relative tense, however, this empty syllable or the lingering low tone (depending on the analysis) are obviously absent. Thus, this tense is not identical to the participial tense. Further evidence is needed from diachrony and/or other Bantu languages that would support such an earlier morpheme in the participial tense, and/or a characteristic tone pattern in the relative clause.

\section{Conclusion}

Relative clauses in Tswana are marked unambiguously by the presence of a relative pronoun and the relative suffix, except for "short relatives" in the present tense. The tone pattern of the verb word in the relative clause corresponds to the tone patterns occurring in the participial tenses, with the exception of the present positive tense which shows an idiosyncracy in lacking the low stem-initial syllable of the participial present tense. As for its prosodic embedding into the head phrase, the relative clause behaves parallel to other (nominal) modifiers in that the last syllable of the preceding head noun cannot become the target for high tone spread. This might be due to phrasing or the tonal environment and is a question that awaits further research by developing a coherent analysis of tonal alternations in Tswana. Another area for further research in connection with tones of the relative clause is the difference in the tonal patterns of the relative present tense and the participial present tense. Here it is cross-Bantu data, both synchronic and diachronic, that is needed to reach at a better-informed classification and evaluation of the two observable tone patterns.

\section{References}

Bresnan, Joan \& Sam Mchombo (1987). Topic, pronoun, and agreement in Chichewa. Language 63 (4), 741-782.

Chebanne, Andrew M., Creissels, Denis \& H.W. Nkhwa (1997). Tonal Morphology of the Setswana verb. Munich: Lincom Europe.

Cheng, Lisa L.-S., and Downing, Laura. To appear. "Against FocusP: arguments from Zulu," in Ivona Kucerova and Ad Neeleman (eds.) Information Structure. Contrasts and Positions. Cambridge: Cambridge University Press.

Cheng, Lisa L.-S., and Downing, Laura. 2007. The prosody and syntax of Zulu relative clauses. In SOAS Working papers in Linguistics 15: 51-63.

Cheng, Lisa \& Nancy Kula (2005). Syntactic and phonological phrasing of Bemba Relatives. Talk at 5th Bantu Grammar: Theory and Description Meeting, SOAS, 11-12 May 2005. 
Cole, Desmond T. \& Dingane M. Mokaila (1962). A Course in Tswana. Washington: Georgetown University.

Cole, Desmond T. (1955). An Introduction to Tswana Grammar. Cape Town: Longman.

Cole, Desmond T. (in press). English-Setswana Illustrated Dictionary.

Creissels, Denis (1998). Expansion and Retraction of High Tone Domains in Setswana. In: Larry M. Hyman \& Charles W. Kisseberth (eds.). Theoretical Aspects of Bantu Tone. Stanford: CSLI, 133-194.

Creissels, Denis (1999). The role of tone in the conjugation of Setswana (S31). In: Blanchon, Jean A. \& Denis Creissels (eds.). Issues in Bantu Tonology. Köln: Rüdiger Köppe, 109-152.

Creissels, Denis (2000). A domain-based approach to Setswana tone. In: H.E. Wolff \& O. Gensler (eds.). Proceedings of 2nd World Congress of African Linguistics, Leipzig 1997. Köln: Rüdiger Köppe, 311-321.

Creissels, Denis. (2002). Présentation du Tswana, Lalies 23: 5-128.

Demuth, Katherine \& Carolyn Harford (1999). Verb raising and subject inversion in Bantu relatives. JALL 20, 41-61.

Doke, Clements M. (1954). The Southern Bantu Languages. London: Oxford University Press.

Jokweni, Mbulelo W. (1995). Aspects of Isixhosa Phrasal Phonology. Unpublished PhD thesis, University of Illinois at Urbana-Champaign.

Kanerva, Jonni M. (1990). Focus and Phrasing in Chichewa Phonology. New York, London: Garland Publishing.

Khoali, Benjamin T. (1991). A Sesotho Tonal Grammar. Unpublished PhD thesis, University of Illinois at Urbana-Champaign.

Lombard, Daniel P. (1976). Aspekte van Toon in Noord-Sotho. Unpublished PhD thesis, University of South Africa.

Mascher, Dieter. (in prep.) A five-year course in Tswana. Ms, Vryburg, South Africa.

Mischke, Gerda (1998). Southern Sotho verbal relative constructions. South African Journal of African Languages 18(4), 106-111.

Mmusi, Sheila O. (1992). Obligatory Contour Principle effects and violations: The Case of Setswana Verbal Tone. Unpublished PhD thesis, University of Illinois at UrbanaChampaign.

Monareng, William M. (1992). A Domain-based Approach to Northern Sotho Tonology: A Setswapo Dialect. Unpublished $\mathrm{PhD}$ thesis, University of Illinois at UrbanaChampaign.

Zeller, Jochen. (2004). Relative clause formation in the Bantu languages of South Africa. SALALS 22(1\&2), 75-93.

Ziervogel, Daniel, Lombard, Daniel P. and P.C. Mokgokong (1969). A Handbook of the Northern Sotho Language. Pretoria: Van Schaik. 